\title{
The Thallus Structure and the Reproductive System of Hyalosiphonia caespitosa (Cryptonemiales, Rhodophyta)
}

\author{
Mrtsuo Chinara and Makoto Yoshizaki \\ Department of Botany, National Science Museum, Taito-ku, Tokyo, 110; \\ Department of Biology, Toho University, Narashino Chiba, 275
}

\begin{abstract}
Detailed morphological studies were carried out on the vegetative thallus and female, and tetrasporangiate systems of the red alga, Hyalosiphonia caespitosa Okamura (family Dumontiaceae). As a result, the following data were obtained: 1) each segment cell produces four vegetative laterals, of which the distal ends form a tight cortex, 2) basal cells of the cortex bear a carpogonial branch and an auxiliary cell branch separately, 3) both carpogonial branch and auxiliary cell branch are strongly curved and 4) after fertilization, the carpogonium fuses with a cell of a carpogonial branch and they form a fused area from which develops a connecting filament which ultimately fuses with the auxiliary cell. These features support well the systematic position of the genus Hyalosiphonia as a taxon of the Dumontiaceae.
\end{abstract}

Hyalosiphonia, a monotypic genus of red algae, with the type species, H. caespitosa, was described by Okamura in 1909 on the basis of specimens collected mainly at Shimabara, Shika and Takashima in Kyushu Is., Japan. It is now known to occur also in various other localities, e.g. Honshu side facing the Japan Sea, Korea and China (Okamura, 1936; Kang, 1966). However, the alga has not been reported from other regions and hence the species appears to be endemic to the East Asia areas. Okamura (1909) has been the only investigator to discuss the systematic position of this alga. He recognized Hyalosiphonia to be a member of the Dumontiaceae because of the presence of the characteristic reproductive system. Kylin (1956) and Segawa (1956) followed Okamura in assigning it to the Dumontiaceae. Recently, we have had field trips to Kyushu district and collected a number of specimens of both gametophytes and tetrasporophytes. These collections made it possible for us to carry out the observations on the morphology of thallus structure as well as on the details of cystocarp formation. The results obtained are described below with some notes about the taxonomy of the alga.

\section{Materials}

Materials used in the present observations were all collected at Tsuyazaki, Fukuoka-ken, Kyushu Is., in March 1969. The specimens were fixed in 5\% formalinseawater and have been preserved in the same solution. 


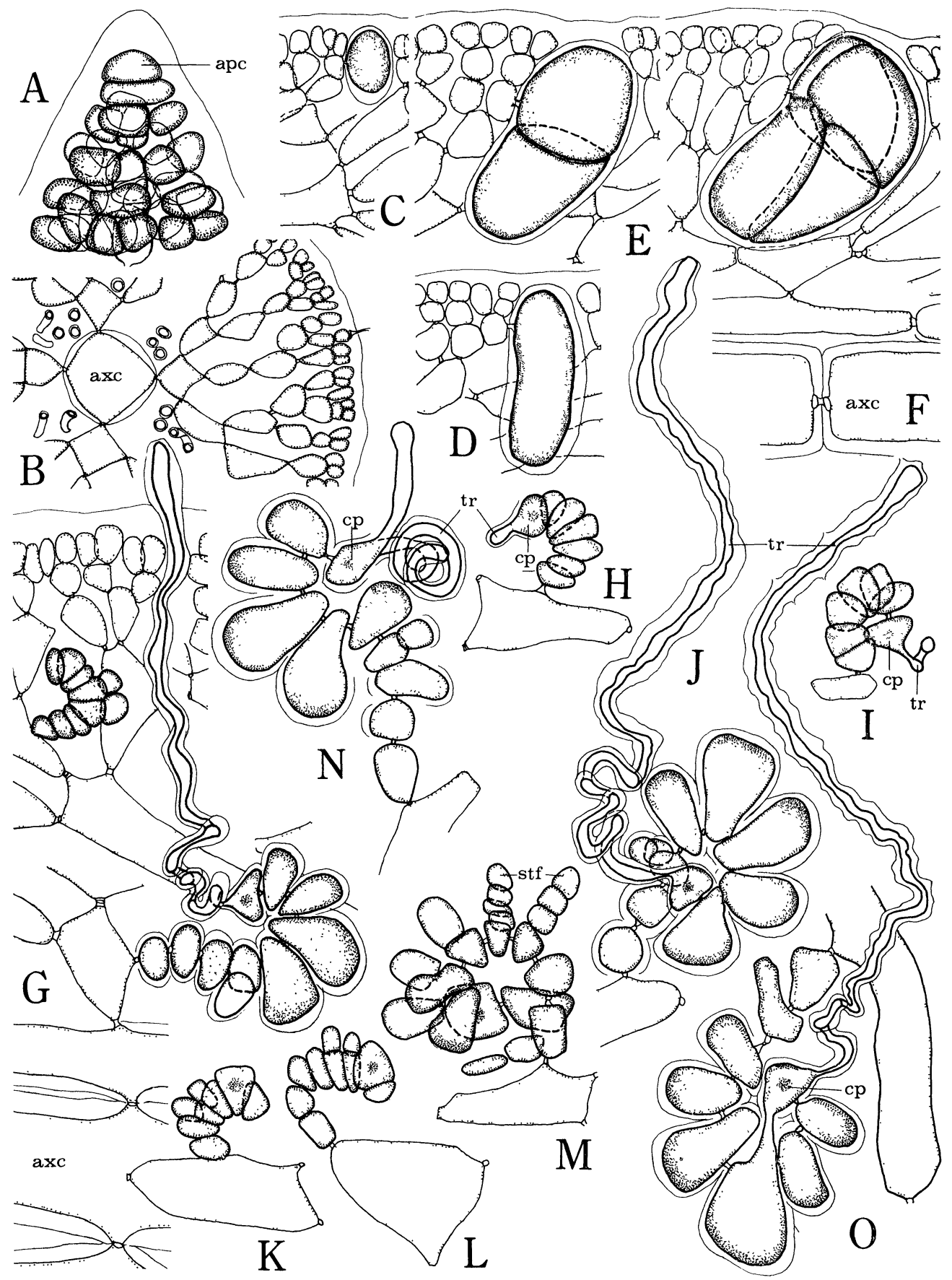

Figs. A-O. Hyalosiphonia caespitosa.

A,B: Vegetative structure of thallus; A: Portion of growing tip, showing an apical cell; B: Transverse section of thallus, showing four laterals arising from an axial segment. C-F: Development of the tetrasporangium; C, D: Longitudinal section of thallus, showing an initial of 


\section{Observations}

Thallus structure and tetrasporangium: The thallus attaches to the substratum by a small discoid holdfast from which one to several erect portions are issued. The erect portion is terete, up to about $40 \mathrm{~cm}$ high and up to about two $\mathrm{mm}$ in diameter, with branches arranged radially and irregularly. The thallus is uniaxial and its growth takes place by transverse division of an apical cell whose shape is conical (Fig. A). The apical cell cuts off by a cross-wall on its lower surface a segment, which in turn cuts off four laterals in a radial direction. These by repeated divisions ultimately constitute a cortex (Fig. B). In its longitudinal section, the thallus is composed of an inner cortical portion and an outer cortical one. The inner cortex is composed of several layers (mostly four layers) of cells which are elongated columnar or linear ovoid to obovate in shape (Figs. B, C, D, E, F). The outer cortex is usually composed of two layers (sometimes three layers) of cells which are ovoid or subspherical in shape (Fig. F) and contain many small discoid plastids.

The tetrasporangium initial is produced as a lateral outgrowth from a cell which is usually the second from the outermost layer of the cortex (Fig. C). With the increase of the size, it becomes ovoid in shape (Fig. D) and then undergoes a cell division which takes place at right angles to the long axis, resulting in two compartments (Fig. E). Each daughter cell is then divided by a cell wall perpendicular to the first formed-cell wall and, as a result, it gives rise to a total of four cells, the tetraspores (Fig. F).

Development of carpogonial branch: The initial of the carpogonial branch arises as a lateral outgrowth from a cell which is situated in the inner cortex; the first, second, third, or fourth cell from the innermost layer is capable of producing a carpogonial branch (Fig. G). The carpogonial branch consists of seven to thirteen cells and its terminal cell is strongly recurved (Figs. H, I, J), showing a typical feature of the Dumontiaceae. The third and fourth cells below the carpogonium are larger than other cells of the branch, and usually the third cell becomes a nutritive cell which fuses directly with the carpogonium after fertilization (Fig. O). Sometimes, the fifth cell behaves as a nutritive cell instead of the fourth cell (Fig. R). The carpogonial branch occasionally bears short laterals (sterile filaments) consisting of several cells (mostly one to five cells). They usually arise from the cells in the lower portion of the branch (Figs. G, J). The trichogyne is long, slender and spirally twisted in the lower portion (Figs. G, J. O).

Development of auxiliary cell branch: The auxiliary cell branch is formed at a similar position to the carpogonial branch; namely, the initial of the auxiliary cell branch arises as a lateral outgrowth from a cell of the inner cortex (Fig. G). The carpogonial

the tetrasporangium; E: Longitudinal section of thallus, showing the sporangium consisting of two compartments; F: Longitudinal section of the thallus, showing the tetrasporangium. G-J: Development of carpogonial branch. K-M: Development of auxiliary cell branch. N,O: Postfertilization development of the female reproductive system; $\mathrm{N}$ : Carpogonial branch, showing a carpogonium with extension towards a nutritive cell; $\mathrm{O}$ : Carpogonial branch, showing complete connection between the carpogonium and the nutritive cell. 


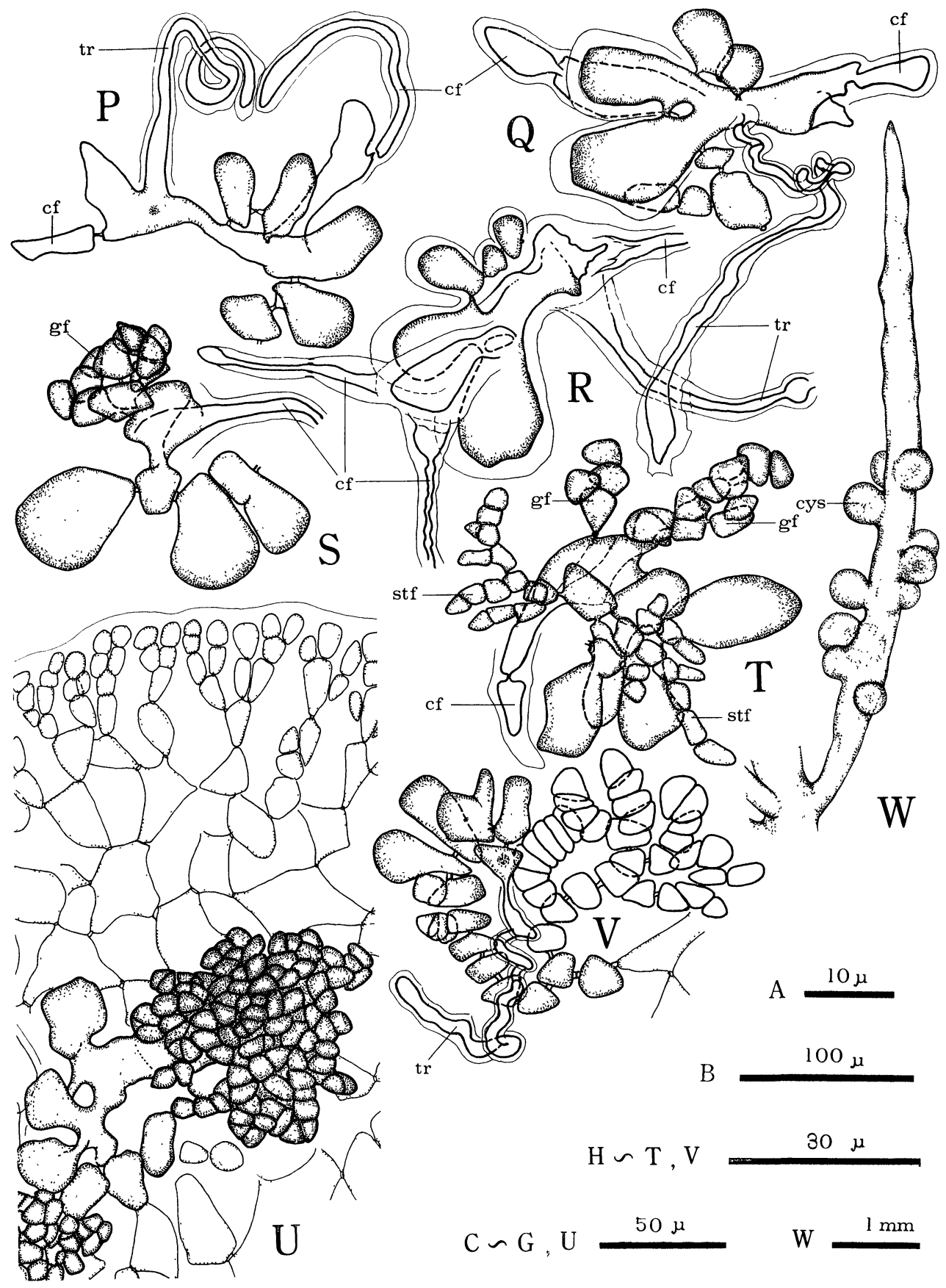

Figs. P-W. Hyalosiphonia caespitosa.

P-U: Postfertilization development of the female reproductive system; P-R: Portions of the carpogonial branch, showing development of connecting filaments from the nutritive cells; S, T: Portions of the auxiliary cell branch, showing development of gonimoblast filaments; U: Portion of cystocarp, showing all the cells of the gonimoblast filaments evolving into carpo- 
branch and the auxiliary cell branch are usually borne on separate supporting cells, but rarely both arise from the same supporting cell (Fig. V). The auxiliary cell branch consists of eight to thirteen cells with recurved terminal cells (Figs. K, L, M). The second cell, rarely the third cell, from the tip is larger than other cells of the branch and it becomes an auxiliary cell as soon as it fuses with a connecting filament issued from a fertilized carpogonium (Fig. S). Occasionally, the third cell from the tip becomes an auxiliary cell. Each cell below the larger cells of the branch is capable of producing sterile filaments distally from its outerside (Fig. M).

Development of cystocarp: After fertilization, the carpogonium produces an extension proximally which usually fuses with the third cell (sometimes the fourth cell) below the carpogonium (Figs. N, O, P, Q, R). The third cell, then, produces usually two or three extensions, each of which elongates towards an auxiliary cell branch and ultimately fuses with one of the cells of the auxiliary cell branch. It usually attaches at the distal portion of the cell. It is interesting to note that the extensions arise also from the fertilized carpogonium (Figs. P, Q, R). After fusion with a connecting filament, the auxiliary cell cuts off gonimoblast initials towards the side where the fusion has taken place (Figs. S, T). The auxiliary cell also cuts off a secondary connecting filament that goes on to another auxiliary cell branch and fuses with its auxiliary cell. Usually, more than two gonimoblast initials arise from one auxiliary cell. Each gonimoblast develops and branches dichotomously, and these branches are so close to one another that a gonimoblast becomes a fairly compact mass (Fig. U). As the gonimoblast develops, an auxiliary cell and adjacent cells of the auxiliary cell branch fuse with one another, ultimately resulting in a massive fused area. All of the gonimoblast cells become carposporangia. Most cells of an auxiliary cell branch cut off lateral filament, which ultimately lie close together and become elongated, but never surround the basal portion of the massive fused area. The carposporangia are ovoid to spherical in shape. As it matures, the cystocarp increases its size gradually and ultimately emerges as an outgrowth beyond the surface of the thallus (Fig. W). Cystocarps are globular in fully developed stages and are scattered over the blanchlets.

\section{Discussion}

The description presented above is essentially in agreement with that of Okamura (1909). In assigning the alga to the Dumontiaceae, Okamura (1909) pointed out the following two characters as criteria of primary importance: 1) presence of an auxiliary cell branch which is strongly curved and 2) the characteristic manner in which the

sporangia. V: Portion of thallus, showing the carpogonial branch and the auxiliary cell branch arising respectively from a single supporting cell. W: Habit sketch of thallus bearing mature cystocarps.

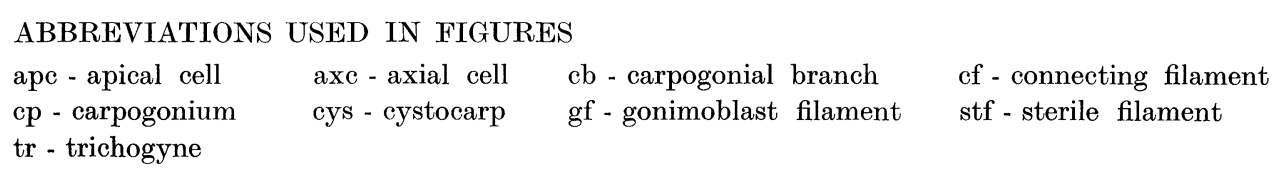


connecting filament develops. According to Hirose (1949) and Kylin (1956), the Dumontiaceae is characterized by 1) the development of the carpogonial branch and the auxiliary cell branch borne on separate supporting cells within the thallus and 2) the fusion of the carpogonium with a certain cell of a carpogonial branch after fertilization, forming a fused area from which develops a connecting filament which ultimately fuses with the auxiliary cell. Recently, Abbott (1968) has carried out comprehensive studies on the morphology and taxonomy of the Dumontiaceae from the northeast Pacific, and as a result, she described two additional characters for the family: 1) each segment cell produces four vegetative laterals, of which the distal ends form a loose or tight cortex and 2) basal cells of the cortex bear a carpogonial branch and an auxiliary cell branch separately. The results of our observations cleary indicate that Hyalosiphonia caespitosa is an alga whose vegetative structure and reproductive systems are in agreement with the characteristics used by Hirose (1949), Kylin (1956) and Abbott (1968) in the circumscription of the family Dumontiaceae.

Among the genera with a terete thallus in the Dumontiaceae, as Okamura (1909) has pointed out, the present alga is closest to the genus Cryptosiphonia in the external habit. With regard to the formation of a firm cortex, the present alga is very similar to Cryptosiphonia (Kylin, 1930) and Dumontia (Kylin, 1923). These three genera are also very similar to one another in their reproductive systems. The one significant character that separates the genus Hyalosiphonia is the presence of the discrete globose cystocarps which emerge beyond the surface of the thallus.*

As described above, Hyalosiphonia caespitosa infrequently produces the carpogonial branch and the auxiliary cell branch on the same supporting cell (Fig. V), a feature also of certain species of Farlowia (Abbott, 1962) and Dudresnaya (Taylor, 1950). This feature is similar to that found in certain other families of the Cryptonemiales, particularly of the family Gloiosiphoniaceae.

We are grateful to Dr. I.A. Abbott, Hopkins Marine Station, Stanford University, for her advice as well as for her reading of the manuscript.

\section{References}

Аввотт, I.A. 1962. Structure and reproduction of Farlowia (Rhodophyceae). Phycologia 2: 29-37.

1968. Studies in some foliose red algae of the Pacific coast. III. Dumontiaceae, Weeksiaceae, Kallymeniaceae. J. Phycol. 4: 180-198.

Chemin, E. 1937. Le développement des spores chez les Rhodophycées. Rev. Gen. Bot. 49: 205-234, 300-327, 253-374, 424-448, 478-536.

Hinose, H. 1949. Contribution to the knowledge of the development of the female organ of

* So far as the Florideophycidae is concerned, the manner of spore germination has been shown to be of diagnostic value for the taxonomy (Killiam, 1914; Chemin, 1937; Inoh, 1947). According to our data (unpublished), the manner of germination of spores of these three genera is similar in all fundamentals. It is of the so-called "immediate discal type". On the contrary, spore germination in Dudresnaya, Acrosymphyton and Pikea, genera all belonging to the Dumontiaceae, is not of "the immediate discal type", but is somewhat similar to "the diprotocellular type". 
Dudresnaya japonica Okamura. Trans. Sapporo. Nat. Hist. Soc. 18: 8-12.

INoH, S. 1947. Kaiso no Hassei. Hokuryukan, Tokyo.

KANG, J.W. 1966. On the geographical distribution of marine algae in Korea. Bull. Pusan Fish. Coll. $7: 1-125$.

Killiam, K. 1914. Über die Entwicklung einiger Florideen. Z. Bot. 6: 209-278.

Kylin, H. 1923. Studien über die Entwicklungsgeschichte der Florideen. K. Sv. Vet-Akad. Handl. 63: 1-139.

1930 U̇ber die Entwicklungsgeschichte der Florideen. Lunds Univ. Årsskr. N.F. Avd. 2. 26: 1-104.

1956. Die Gattungen der Rhodophyceen. CWK Gleerups, Lund.

OKamura, K. 1909. Icones of Japanese Algae II. Kazamashobo, Tokyo.

SEgawa, S. 1956. Coloured Illustrations of the Seaweeds of Japan. Hoikusha, Osaka.

TAYLOR, W.R. 1950. Reproduction of Dudresnaya crassa Howe. Biol. Bull. 99: 272-284. 